\title{
Integrasi Hukum Positif dengan Budaya Daerah dalam Sistem Hukum Indonesia
}

\author{
KAHAR \\ Institut Agama Islam DDI Polewali Mandar \\ Email : kahar@ddipolman.ac.id
}

\begin{abstract}
Abstrak
Tulisan ini berjudul "Integrasi Hukum Positif Dengan Budaya Daerah Dalam Sistem Hukum Indonesia" judul ini diangkat karena peraturan perundang-undangan sebagai hukum positif harus memperhatikan nilai-nilai hukum yang hidup dalam masyarakat. Dari judul tersebut, maka permasalahan yang ditarik adalah bagaimana impelementasi integrasi hukum positif dengan budaya daerah dalam sistem hukum Indonesia dapat diiplementasikan.

Penulisan ini menggunakan penelitian hukum normatif atau penelitian hukum doktrinal, yang lazimnya disebut "Legal Research" atau "Legal Research Instruction". Penelitian ini identik penelitan kepustakaan (library research). Penelitian semacam ini, sering juga disebut studi hukum dalam buku (law in books), menekankan pada langkah-langkah spekulatif-teoritis dan analisis normatif-kualitatif. Penelitian hukum normatif atau penelitian hukum doktrinal berdasarkan data sekunder yang terdidri dari bahan hukum primer, bahan hukum sekudner dan bahan hukum tersier. Pendekatan yang digunakan adalah pendekatan konseptual (conseptual approach), dalam hubungan ini orientasi penelitian hukum normatif adalah law in books, dengan mengurai doktirn-doktrin hubungan hukum positif dengan budaya daerah.

Hasil penelitian ini, menggambarkan bahwa integrasi hukum positif dengan budaya daerah adalah kebutuhan dalam praktikal maupun teoritikal sehingga pengimplementasian hokum positif tidak terbebani dengan nilai-nilai budaya daerah.Rekomendasi, kiranya pekerjaan para legislatif dalam menyusun hukum positif sedapat mungkin memperhatikan budaya daerah agar tidak saling berhadap-hadapan anatara hukum positif dengan budaya daerah.
\end{abstract}

Kata Kunci: implementasi Hukum positif diintegrasikan dengan nilai-nilai budaya daerah.

\section{A. Pendahuluan}

Melihat fenomena penegakkan hukum dewasa ini membuat orang semakin kurang respect terhadap penyelenggaraan penegakkan hukum, karena seoalah tidak ada kemajuan, padahal peradaban manusia jalan dan maju terus, seiring dengan pradaban dunia sehingga penegakkan hukum dimaknai dalam situasi degredasi yang oleh B. Arief Sidharta sebagai disebut kemandekan dan keterpurukan penegakkan hukum. Kemandekan dan keterpurukan penyelenggaraan penegakkan hukum di Indonesia disebabkan oleh pradigma tentang hukum dan ilmu hukum yang didominasi dan dibelenggu oleh pradigma positivisme baik dalam tataran praktikal maupun dalam tataran teoritikal. Untuk dapat keluar dari kemandekan dan keterpurukan penyelenggaraan penegakkan hukum di Indonesia maka diperlukan pengembangan teori-teori dan pemikiran tentang hukum yang mampu menembus dan melangkahi batas-batas yang dipatok 
prdigma positivisme hukum. Artinya saat ini sudah diperlukan untuk mengajukan suatu pradigma hukum yang baru yakni pemikiran baru tentang hukum yang berbeda dari yang sudah dilazimkan sejak pertengahan abad XIX, demikian menurut B. Arief Sidharta. ${ }^{1}$ Salah satu pemikiran meskipun masih amat kecil dari pemikiran positivisme hukum adalah adalah integrasi hukum positif dengan budaya daerah.

Mempersoalkan "Integrasi Hukum

Positif dengan Budaya Daerah Dalam Sistem Hukum Negara Indonesia" adalah persoalan yang akan memberi kontribusi pada politik hukum karena politik hukum menurut Teuku Mohammad Radhie adalah merupakan kehendak penguasa dari suatu negara mengenai tatanan hukum yang akan diberlakukan serta ke arah mana hukum akan dikembangkan. ${ }^{2}$ Dengan demikian penentuan hukum yang akan dinyatakan berlaku pada suatu negera tertentu merupakan ranah politik hukum. Politik hukum dapat juga digambarkan sebagai "Legal Policy" atau garis (kebijakan) resmi tentang hukum yang akan diberlakukan baik dengan pembuatan hukum baru maupun dengan penggantian hukum lama, dalam rangka mencapai tujuan negara". Politik hukum merupakan pilihan tentang hukum-hukum yang akan diberlakukan sekaligus pilihan tentang hukum-hukum yang akan dicabut atau tidak diberlakukan yang kesemuanya dimaksudkan untuk mencapai tujuan negara seperti yang tercantum di dalam pembukaan UUD $1945 .^{3}$

Dalam mengkaji integrasi hukum positif dengan budaya daerah di Indoensaia akan dilandasi konstitusi yakni Pasal 1 ayat (3) Undang-Undang Dasar Negara Republik Indonesia(UUD RI) hasil amandemen. Yang merumuskan: Negara Indonesia adalah negara hukum. Impelementasi Indonesia sebagai negara hukum yang dimaksud dalam Pasal 1 ayat (3) tersebut di atas, tertuang dalam Pasal 27 ayat (1) UUD RIyang rumusannya: segala warga negara bersamaan kedudukannya di dalam hukum dan pemerintahan dan wajib menjunjung hukum dan pemerintahan itu dengan tidak ada kecualinya.

Demikian pula dalam Pasal 28 D UUD 1945 yang merumuskan bahwa: setiaporang berhak atas pengakuan, jaminan, perlindungan,dan kepastian hukum yang adil serta perlakuan yang sama di hadapan hukum.Dari kedua rumusan tersebut merupakan instrumen yang amat penting untuk selalu mendapat perhatian. Fakta di atas membenarkan tulisan Ahmad Gunaryo, bahwa hukum itu adalah identitas suatu bangsa, ketika sarjana hukum tidak mau lagi membicarakan hukum, maka habislah identitas bangsa ini. ${ }^{4}$ Sehubungan dengan itu, Satjipto Rahardjo menyeruhkan, hendaklah fakultas-fakultas hukum selalu resah dan gelisah melihat keterpurukan hukum bangsanya, dan segera merubah siasat pembelajaran dan teori-teorinya agar secara progresif dan proaktif mengubah kultur komunitas profesi hukum di masa datang

\footnotetext{
${ }^{1}$ Anthon F. Susanto, Hukum dari Consilience ke Pradigma Hukum Konstruktif-Transgresif (Bandung: Rafika Aditama, 2017), h. x.

${ }^{2}$ E. Sundari \& M.G. Endang Sumiarni, Politik Hukum dan Tata hukum Indonesia (Yogyakarta: Cahaya Atma Pustaka, 2015), h. 3.
}

\footnotetext{
${ }^{3}$ Moh. Mahfud MD, Politik Hukum di Indonesia (Jakarta: Rajawali Pers, 2009), h. 1.

${ }^{4}$ Kahar, Menguak Penemuan Hukum Berwibawa (Samata-Gowa: Gunadarma Ilmu, 2016), h. 1 .
} 
yang dekat. ${ }^{5}$ Apa yang dikemukakan Ahmad Gunaryo seirama dengan Satjipto Rahardjo, akan tetapi perbaikan dan penegakkan hukum bukan semata-mata ditentukan oleh para sarjana hukum sebagai out put (lulusan) dari fakultas hukum atau perguruan tinggi hukum, melainkan semua pihak yang menaruh parhatian terhadap penegakkan hukum sebab hukum ada ditenga-tengah kehidupan warga masyarakat yang plural. Hal demikian telah pernah digambarkan oleh Talcott Parsons seorang ahli sosiologi hukum (dalam bukunya "The Social System") yang terkenal dengan Teori Sibernetik-nya bahwa hukum dalam masyarakat berdampingan dengan sub-sub bidang lain, yaitu: kebudayaan, sosial, politik, dan ekonomi. ${ }^{6}$ Demikian pula pandangan von Savigny yang inti ajarannya adalah "das recht wird nicht gemacht, est ist und wird mit dem volke" (hukum itu tidak dibuat, tetapi tumbuh dan berkembang bersama masyarakat. Pandangannya bertitik tolak bahwa di dunia ini terdapat banyak bangsa, dan tiap-tiap bangsa memiliki volksgeistjiwa rakyat. Jiwa ini berbeda, baik menurut waktu maupun tempat. Pencerminannya nampak pada kebudayaan masing-masing yang berbeda-beda. ${ }^{7}$ Dalam kaitannya dengan sistem hukum Indonesia tentu masuk bidang religi dan adat.

Secara historis negara hukum, dapat dikemukakan dengan menyetir pendapat ahli terkemuka dibidang hukum yang mengurai ciri-ciri negara hukum dengan memperkenalkan unsur-unsuratau elemen negara hukum tersebut, yakni:

\footnotetext{
${ }^{5}$ Kahar, Menguak Penemuan Hukum Berwibawa, h. 1.

${ }^{6}$ Achmad Ali, Menguak Tabir Hukum (Jakarta: Pustaka Prima, 1988), h. 195.

${ }^{7}$ Lili Rasjidi, Filsafat Hukum Apakah Hukum itu? (Bandung: Remaja Rosdakarya, 1993), h. 47-48.
}

1. Dalam Sistem hukum EropaKontinental / Civil law, yang oleh J. Stahl disebutnya dengan istilah rechtstaat yang mencakup empat elemen penting, yaitu ;
a. Perlindungan hak-hak asasi manusia;
b. Pemisahan atau pembagian kekuasaan untuk menjalankan hak- hak;
c. Pemerintahan berdasarkan peraturan perundang-undangan;
d. Peradilan administrasi dalam perselisihan.

2. Dalam Sistem hukum Anglo-Saxon / Common Law, yang oleh A.V.Dicey menyebutnya The Rule of Law bercirikan:

a. Supermasi aturan-aturan hukum, tidak adanya kekuasaan yang sewenang-wenang, (Supremacy of Law);

b. Kedudukan yang sama di depan hukum, (Equality Before The Law);

c. Terjaminnya hak-hak asasi manusia dalam undang-undang (deu Process of Law). ${ }^{8}$

Dalam melihat sistem hukum, para pakar comparative law (perbandingan hukum) termutakhir, tidak lagi hanya membedakan adanya dua sistem hukum di dunia tersebut di atas, yang hanya dipandang berdasarkan "kacamata Barat", yaitu common law system (Anglo-Anerican Legal System) yang didominasi hukum tak tertulis dan precedent (putusan pengadilan terdahulu), dan kedua, civil law (Continental Eropa legal System), yang didominasi oleh hukum undang-undang, melainkan dewasa ini sudah dikenal

8 Jimly Asshidiqie, Menuju Negara Hukum Yang Demokratis (Jakarta: PT. Bhuana Populer, 2009), h. 396. 
pembedaan sistem hukum yang lebih variatif. Salah satunya pembedaan berikut:

1. Civil law, berlaku di Benua Eropa dan negara-negara mantan jajahannya,

2. Common law, berlaku di Inggris. Amerika Serikat, dan negara-negara berbahasa Inggris (Commonweth).

3. Customary law, di beberapa negara Afrika, Cina, dan India.

4. Muslim law, di negara-negara muslim, terutama di Timur Tengah.

5. Mixed system, di Indonesia salah satunya, di mana berlaku sistem hukum perundang-undangan, hukum adat, dan hukum Islam. ${ }^{9}$

\section{B. Batasan Integrasi,}

Secara garis besar, dalam Kamus Besar Bahasa Indonesia Edisi Ketiga, dituliskan "integrasi" adalah pembauran hingga menjadi kesatuan yang utuh atau bulat. Berintegrasi berartiberpadu.

Mengintegrasikan, menggabungkan, menyatukan. ${ }^{10}$ Menggabungkan bukan berarti menghilangkan identitas salah satu pihak, karena keberagaman adalah salah satu ciri bangsa Indonesia yang tidak boleh dihilangkan, termasuk di dalamnya antara budaya dan hukum positif adalah tidak sama, tetapi diintegrasikan untuk saling melengkapi demi kepentingan masyarakat, bangsa dan negara Indonesia.

Anthon F. Susanto, menulis "Hukum dari Consilience ke Pradigma Hukum Konstruktif-Transgresif" memberi makna consilinece sebagai lompatan bersama dalam hal pengetahuan dengan jalan

${ }^{9}$ Achmad Ali, Menguak Teori Hukum (Legal Theory) dan Teori Peradilan (judicialprudence) Termasuk Interpretasi Undang-undang (Legisprudence), (Jakarta: Prenada Media group, 2009). h. 203.

${ }^{10}$ Pusat Bahasa Departemen Pendidikan Nasional, (Jakarta: Balai Pustaka, 2003), h. 437. mempertalikan dan mempersatukan faktafaktadan teori di seluruh disiplin ilmu guna menciptakan satu dasar penalaran atau alasan yang sama untuk memberikan keterangan keterangan. ${ }^{11}$ karena itu integrasi dapat di rujukan dengan consilience yang dimaknai mempertalikan atau mempersatukan dalam gerakan bersama.

Dalam kehidupan sosial kemasyarakatan, diperkenalkan bahwa integrasi dapat dilihat dari beberapa bentuk, antara lain:

1. Asimilasi, dua atau lebih kebudayaan dipadukan yang hasilnya menghilangkan khas dari kebudayaan asli, artinya hasil dari asimilasi merupakan sebuah kebudayaan baru yang diterima oleh semua kelompok dalam lingkungan masyarakat yang bersangkutan.

2. Akulturasi, penggabungan dua atau lebih kebudayaan tanpa menghilangkan ciri khas kebudayaan asli di lingkungan tersebut. Biasanya kebudayaan asing yang masuk akan mendapatkan penolakan terlebih dahulu, akan tetapi kemudian seiring berjalannya waktu kebudayaan ini akan diterima dan dimanfaatkan dengan tanpa menghilangkan ciri khas dari kebudayaan awal.

3. Integrasi normatif, adalah integrasi yang terjadi karena norma-norma tertentu yang berlaku dalam masyarakat secara keseluruhan. Norma ini menjadi hal yang mampu mempersatukan masyarakat sehingga integrasi lebih mudah terbentuk.

4. Integrasi instrumental, adalah integrasi yang tanpak secara visual akibat adanya keseragamanantara individu dalam suatu lingkungan masyarakat. Sebagai

${ }^{11}$ Anthon F. Susanto, Hukum dari Consilinece ke Pradigma Hukum Konstruktif - Transgresif, h. 68. 
contoh: keseragaman busana, kostum, kegiatan.

5. Integrasi ideologis, adalah integrasi yang tidak tampak secara visual, terbentuk karena adanya ikatan spritual atau ideologi yang kuat berdasarkan proses alamiah tanpa adanya paksaan. Integrasi ideologis menggambarkan adanya persamaan kepahaman dalam memandang nilai sosial, persepsi, serta tujuan antara anggota masyarakat dalam lingkungan masyarakat yang bersangkutan.

6. Integrasi koersif, merupakan integrasi yang terbentuk karena adanya pengaruh kekuasaan yang dimiliki oleh penguasa. Integrasi ini dapat bersifat intimidasi.

\section{Hukum Positif,}

Istilah positif berasal dari kata 'posivere' yang berarti pasti. Hukum positif berarti hukum yang diorientasikan pada kepastian hukum, bukan keadilan, apalagi kesejahteraan. Hukum positif didasarkan pada falsafah positivisme Eropah. ${ }^{12}$

Hukum positif adalah terjemahan dari istilah ius positum(Bahasa Latin), secara harafiah berarti "hukum yang ditetapkan" (gesteld recht). Jadi, hukum positif adalah hukum yang ditetapkan oleh manusia, karena itu dalam ungkapan kuno disebut stellig recht. Menurut N. Algra dn K. van Duyvendak dalam bukunya Rectsaanvang, istilah lain hukum positif

12 Dominikus Rato, Hukum Adat Kontemporer (Surabaya: LaksBang Justitia, 2015), h. 69 . adalah hukum yang berlaku (gelden recht). ${ }^{13}$

Dari pendapat ahli hukum tersebut dapat ditarik pengertian atau definisi hukum positif.Pertama; hukum positif (ius positum) itu ditetapkan oleh manusia atau oleh penguasa (pembuat hukum) yang berwenang untuk masyarakat tertentu dalam wilayah tertentu. Kedua; hukum positif (ius positum) identik atau sama dengan ius constitutum, artinya hukum yang telah dipilih atau ditentukan atau ditetapkan berlakunya untuk mengatur kehidupan di tempat tertentu pada waktu sekarang. ${ }^{14}$

Dalam hubungannya dengan hukum positif. John Austin, ${ }^{15}$ membagi hukum menjadi dua macam:

1. Hukum Tuhan, hukum Tuhan tidak mempunyai fungsi yuridis, namun hukum Tuhan hanya berfungsi menjadi wadah-wadah kepercayaan utilitarian, yaitu pada prinsip kegunaannya dan;

2. Hukum manusia (undang-undang yang diadakan oleh manusia untuk manusia) hukum manusia menjadi dua lagi:

2.1. Hukum dalam arti sebenarnya, disebut hukum positif

a) Hukum yang dibuat oleh kekuasaan pemerintah biasa disebut undang-undang, peraturan pemerintah, dan lain-lain. Yang ciri-cirinya menurut Austin, hukum yg sebenarnya mengandung 4 unsur; yaitu: 1. perintah, 2. sanksi, 3. kewajiban, 4.

\footnotetext{
${ }^{13}$ Umar Said Sugiarto, Pengantar Hukum Indonesia (Jakarta: Sinar Grafika, 22013), h. 4.

${ }^{14}$ Umar Said Sugiarto, Pengantar Hukum Indonesia, h. 4.

${ }^{15}$ Salim HS, Perkembangan Teori dalam Ilmu Hukum (Jakarta: Rajawali Pres, 2012), h. 22.
} 
kedaulatan. (Lili Rasjidi, 1993: 43)

b) Hukum yang dibuat oleh rakyat secara individual, yang dipergunakan untuk melaksanakan hak-hak yang diberikan kepadanya.

2.2. Hukum dalam arti yang tidak sebenarnya, yaitu hukum yang tidak memenuhi persyaratan sebagai hukum. Jenis hukum ini tidak dibuat atau ditetapkan oleh penguasa / badan berdaulat yang berwenang. Contoh: ketentuanketentuan yang dibuat oleh perkumpulan-perkumpulan atau badan-badan tertentu dalam bidang keolahragaan. Mahasiswa, dan sebagainya.

Sebagai hukum yang ditetapkan terdapat empat unsur penting untuk dinamakan sebagai hukum, yakni: 1. Ada Perintah; 2. Ada Sanksi; 3. Ada Kewajiban; dan 4. Ada Kedaulatan.

Ad.1 Perintah; adalah aturan yang harus dilaksanakan, baik oleh warga masyarakat maupun oleh pembentuk hukum positif. Contoh perintah adalah semua orang tidak diperkenankan untuk mencuri, membunuh, atau perbuatan melawan hukum.

Ad.2 Sanksi; merupakan hukuman yang dijatuhkan kepada orang yang tidak mematuhi perintah dan larangan.

Ad.3 Kewajiban; adalah sesuatu yang harus dilaksanakan. Misalnya orang yang berutang berkewajiban membayar utangnya.

Ad.4 Kedaulatan; adalah kekuasaan yang dimiliki, baik oleh negara maupun seseorang kepada orang lain.
Sehubungan dengan empat unsur penting untuk dinamakan sebagai hukum, maka sejalan pula dengan Leopold Pospisil, yang menamakan attribute of law atau ciriciri hukum, menurut Pospisil, ada empat atribut khas kaidah hukum yang membedakannya dengan kaidah sosial lain dalam masyarakat. Keempat atribut tersebut adalah:

1. Attrribute of authority, yaitu bahwa hukum merupakan keputusan dari pihak-pihak yang berkuasa dalam masyarakat, keputusan mana ditujukan untuk mengatasi keteganganketegangan yang terjadi di dalam masyarakat.

2. Attribute of intention of universal application, yaitu keputusan yang mempunyai daya jangkau yang panjang untuk masa mendatang,

3. Attribute of obligation merupakan ciri di mana keputusan pengawasan yang harus berisi kewajiban-kewajiban pihak pertama terhadap pihak kedua dan sebaliknya. Dalam hal ini semua pihak harus masih dalam keadaan hidup.

4. Attribute of sanction yang menentukan bahwa keputusan dari pihak berkuasa harus dikeluarkan dengan sanksi, yang didasarkan pada kekuasaan masyarakat yang nyata. ${ }^{16}$

Dari rangkaian uraian di atas, maka hukum positif atau ius constitutum adalah hukum yang dinyatakan berlaku dalam suatu waktu dan tempat tertentu. Karena itu, dalam pandangan hukum positif, hukum dapat didefiniskan: "serangkaian aturan yang berisi perintah dan larangan yang dibuat oleh otoritas tertinggi dalam suatu negara dan bangsa,

${ }^{16}$ Achmad Ali, Menjelajahi Kajian Empiris Terhadap Hukum (Jakarta: Kencana, 2012), h. 134135. 
yang apabila dilanggar akan menimbulkan sanksi baik internal maupun eksternal. ${ }^{17}$

Dengan demikian hukum positif adalah hukum yang menjamin, menopang atau menunjang "asas legalitas" dalam bahasa Latin,"Nullum Delictum Nulla Poena Sine Praevia Lege Poenali" arti bebasnya; "Tiada Suatu Peristiwa dapat dipidana selain kekuatan undang-undang pidana yang mendahuluinya ditetapkan oleh otoritas tertinggi”.

Adapun bentuk hukum positif dapat dilihat dalam Pasal 7 ayat (1) dan Pasal 8 Undang-undang No. 12 tahun 2011 Tentang Pembentukan Peraturan Perundang-Undangan, yang rumusannya: Pasal 7 (1) Jenis dan hierarki Peraturan Perundang-undangan terdiri atas:

a. Undang-Undang Dasar Negara Republik Indonesia Tahun 1945;

b. Ketetapan Majelis Permusyawaratan Rakyat;

c. Undang-Undang/Peraturan Pemerintah Pengganti Undang-Undang;

d. Peraturan Pemerintah;

e. Peraturan Presiden;

f. Peraturan Daerah Provinsi; dan

g. Peraturan Daerah Kabupaten/Kota. Pasal 8 ayat (1) Jenis Peraturan Perundang-undangan selain sebagaimana dimaksud dalam Pasal 7 ayat (1) mencakup peraturan yang ditetapkan oleh Majelis Permusyawaratan Rakyat, Dewan Perwakilan Rakyat, Dewan Perwakilan Daerah, Mahkamah Agung, Mahkamah Konstitusi, Badan Pemeriksa Keuangan, Komisi Yudisial, Bank Indonesia, Menteri, badan, lembaga, atau komisi yang setingkat yang dibentuk dengan Undang-Undang atau

${ }^{17}$ Saksi internal adalah saksi yang sifatnya dari dalam diri yang bersangkutan seperti perasaan bersalah, menyesali perbuatannya. Sanksi eksternal, adalah ganjaran atas pelaku yang bersifat penghukuman badan atau pemberian beban lain pada pelaku pelanggaran yang sifatnya memaksa.
Pemerintah atas perintah UndangUndang, Dewan Perwakilan Rakyat Daerah Provinsi, Gubernur, Dewan Perwakilan Rakyat Daerah Kabupaten/Kota, Bupati/Walikota, Kepala Desa atau yang setingkat.

\section{Budaya Daerah}

Dalam literatur terdapat banyak pandangan dalam mengkonsepkan budaya sehingga merupakan sesuatu yang lumrah dan wajar apabila terdapat beragam konsep tentang budaya. Kamus Besar Bahasa Indonesia menguraikan: budaya adalah pikiran, akal budi, hasil. ${ }^{18}$ Menurut Syamsuddin Pasamai, budaya adalah hasil karya, cipta, dan karsa manusia. ${ }^{19}$ Manusia adalah mahluk sempurna ciptaan Tuhan Yang Maha Kuasa, karena memiliki:

1. Akal, untuk berpikir, sebagai sumber Ilmu pengetahuan dan teknologi, dengan akal manusia menilai mana yang benar dan mana yang salah,.

2. Perasaan, alat untuk menyatakan keindahan, sebagi sumber seni. Dengan perasaan manusia menilai mana yang indah / estetis dan mana yang jelek.

3. Kehendak, adalah alat untuk menyatakan pilihan, sebagai sumber kebaikan. Dengan kehendak manusia menilai mana yang baik dan mana yang buruk. Sebagi sumber nilai moral. ${ }^{20}$

Harsya Bachtiar, dalam pandangan modern, budaya dikonsepkan secara terbatas atau sempit, yakni sebatas

${ }^{18}$ Departemen Pendidikan Nasioan, Kamus Besar Bahasa Indonesia (Jakarta; Balai Pustaka, 2003), h. 169.

${ }^{19}$ Disampaikan oleh Prof.Dr. Syamsuddin Pasamai, S.H.,M.H. selaku penguji dalam ujian Tesis penulis pada tanggal 29 Maret 2010. Bahwa, menurut Koentjaraningrat, budaya adalah hasil karya, cipta, dan karsa manusia.

${ }^{20}$ Abdul Kadir Muhammad, Etika Profesi Hukum (Bandung: Citra Aditya Bakti, 2006), h. 1. 
sistem lambang. Sistem material dan sistem sosial tidak termasuk dalam konsep budaya, meskipun berkaitan, berkelindaan, bahkan tidak terpisahkan dengan sistem lambang. ${ }^{21}$ Sebagai sebuah sistem lambang, budaya berkenaan atau bersangkutan dengan kompleksitas hayatan, renungan, gagasan, pikiran, pandangan, dan nilai yang pada hakikatnya merupakan ekspresi dan eksternalisasi kegiatan budi manusia dalam menjalani, mempertahankan, dan mengembangkan hidup dan kehidupannya di dunia.

Dengan demikian, budaya sebagai
sistem lambang terkait dengan
kompleksitas kegiatan cipta, rasa, dan karsa
manusia, sehingga budaya sering dipersepsi, dipahami, dan dipandang sebagai sistem makna atau pengetahuan dan sistem nilai. Sistem makna (system of meaning) melahirkan ide-ide kognitif, sedangkan sistem nilai (system of value) melahirkan ide-ide normatif. Baik sistem makna maupun sistem nilai sebenarnya selalu melekat (inheren) pada budaya sebagai sistem lambang, karena kedua sistem ini secara serempak dan niscaya akan mencipta dan mencipta ulang dunia di dalam budaya sebagai sistem lambang (the simbolic systems make and remake the world). ${ }^{22}$

Dalam penyelenggaraan pemerintahan, dikenal adanya asas-asas umum pemerintahan yang baik yang termuat dalam Pasal 3 Undang-undang No. 28 tahun 1999 tentang Penyelenggara Negara Yang Bersih dan Bebas dari Korupsi. Terdiri dari:

\footnotetext{
${ }^{21}$ Harsya Bachtiar, Sistem Budaya di Indonesia, Budaya dan Manusia di Indonesia (Yogyakarta: Hanindita, 1986), h. 66-67.

${ }^{22}$ M. Syamsuddin, Konstruksi Baru Budaya Hukum Hakim Berbasis Hukum Progresif (Jakarta: Kencana Prenada Media Group, 2012), h. 23-24.
}

1. Asas Kepastian Hukum,

2. Asas tertib penyelenggara negara,

3. Asas kepentingan umum,

4. Asas keterbukaan,

5. Asas proporsionalitas,

6. Asas Profesionalitas,

7. Asas akuntabbilitas.

Salah satu asas pemerintahan yang baik selain tersebut dalam pasal 3 di atas, diperkenalkan oleh beberapa ahli hukum administrasi negara yang berkaitan dengan asas otonomi daerah dengan sebutan "asas kearifan lokal". Asas tersebut tentu berkaitan dengan budaya daerah yang mempunyai nilai-nilai hukum tersendiri serta mempunyai ciri dan karakter masingmasing yang berbeda antara satu dengan lainnya.

Salah satu contoh nilai budaya yang berkaitan dengan penegakan hokum dapat disimak pada lagu "MESA KANNE" ciptaan Suparman Supu dan Sabri Maulana yang disenandaungkan Andi Muhammad AliBaal Masdar (Gubernur Sulawesi Barat) pesan lagu tersebut " bersatu dalam kebenaran dan keadilan adalah prinsip hidup bersama di tanah mandar di pitu ulunna salu, di pitu bab'ban binanga bersama menjalankan sunatullah". Oleh karena itu, lagu tersebut penuh nilai-nilai budaya yang berkaitan dengan penegakkan hokum. Lirik lagu "mesa Kanne" yang menurut penulis amat relevan dengan penegakkan hokum adalah:

\section{"Mappa Peko Pulu Sodo" \\ "Mappa Roro Pulu Pae" \\ Bila diterjemakan dengan bebas:}

1. Arti kata "Mappa Peko Pulu Sodo", adalah membengkokan pegangan sabit. Dalam sejarah pekerja kebun, sabit adalah alat yang dipakai pekerja kebun untuk membersihkan kebun dengan cara didorong truk dana didorong lagi. Dari dulu sampai sekarang 
pegangannya selalu bengko, sebab kalau lurus tidak akan berfungsi sehingga memang demikianlah bentuknya selalu bengkok (peko)yang ber argumentum a contario dengan lurus.

Apabila makna yang terkandung dalam lirik "Mappa Peko Pulu Sodo" (membengkokan pegangan sabit) dihubungkan dalam penegakkan hukum maka dapat diabstraksikan "yang salah tetap salah" jangan yang salah dibenarkan atau yang salah tetap salah.

2. Arti kata "Mappa Roro Pulu Pae" adalah meluruskan pegangan pahat.

Dalam sejarah pertukangan, pahat adalah alat untuk melubang kayu dengan cara memukul ujung pegangan sehingga pegangannya selalu lurus, kalau pegangan pahat dibengkokan, maka pahat tersebut tidak akan berfungsi Karen tidak bisa dipukul kalau bengkok.

Apabila makna yang terkandung dalam lirik "Mappa Roro Pulu Pae" (meluruskan pegangan pahat) dihubungkan dalam penegakkan hukum maka dapat diabstraksikan "yang lurus tetap lurus atau yang benar tetap benar.

Penulis mengangkat nilai-nilai budaya tersebut untuk dihubungkan dengan penegakkan dan pengembangan hukum apabila dengan tema integrasi hukum postif dengana budaya daerah, karena konstitusi kita nilai-nilai hukum dalam masyarakat diakui keberlakuannya oleh undang-undang kekuasaan kehakiman, sebagaimana terbaca dalam Pasal 5 ayat (1) Undang-undang No. 48 tahun 2009 tentang Kekuasaan Kehakiman, yang rumusannya:

Hakim dan hakim konstitusi wajib menggali, mengikuti, dan memahami nilai-nilai hukum dan rasa keadilan yang hidup dalam masyarakat.

\section{E. Sistem Hukum Indionesia}

Bahwa secara historis dan faktual, Indonesai adalah bekas jajahan Belanda maka hukum peninggalan Belanda masih ada yang digunakan sampai sekarang, dengan merujuk pada pasal I aturan Peralihan Undang-Undang Dasar 1945 bahwa: Segala Peraturan perundangundangan yang ada masih tetap berlaku sebelum diadakan yang baru menurut Undang-Undang Dasar ini, adapun hukum yang masih berlaku: seperti Hukum Pidana Hukum Perdata, Hukum Acara Perdata $(H I R, R . B g, R v)$ dan peraturan lain dari peninggalan Belanda masih diberlakukan. Sistem hukum yang berlaku di negeri Belanda adalah sistem hukum Eropa Kontinental dengn sebutan Civil Law System. Jadi Indonesia menganut Civil Law System yang di dominasi peraturan perundang-undangan. Ini diperkuat dengan adanya azas legalitas yang intinya orang tidak bisa dihukum kecuali apa yang dilakukannya telah diatur dalam peraturan perundang-undang. Yang oleh Rusli Effendy (1986 : 22) mengemukakan bahwa azas legalias mengandung tiga pengertian yakni:

1. Tidak ad suatu perbuatan yang dapat dipidanakan kalau hal itu tidak diatur dalam suatu peraturan perundangundangan sebelumnya.

2. Untuk menetukan adanya peristiwa pidana tidak boleh digunakan analogi,

3. Peraturan-peraturan pidana tidak boleh berlaku surut.

Tetapi berdasarkan dengan Pasal 10 ayat (1) Undang-undang No. 48 Tahun 2009 tentang Kekuasaan Kehakiman berbunyi: Pengadilan dilarang 
menolak untuk memeriksa, mengadili, dan memutus suatu perkara yang diajukan dengan dalih bahwa hukum tidak ada atau kurang jelas,melainkan wajib untuk memeriksa dan mengadilinya. Pasal tersebut sebelumnya telah di dukung oleh Pasal 5 ayat (1) Undang-undang No. 48 Tahun 2009 tentang Kekuasaan Kehakiman yang berbunyi: Hakim dan hakim konstitusi wajib menggali, mengkuti, dan memahami nilai-nilai hukum dan rasa keadilan yang hidup dalam masyarakat.

Dari kedua pasal tersebut (pasal 5 dan pasal 10), maka Indonesia juga menganut common law system yang $\mathrm{di}$ dominasi hukum tak tertulis, dan karena Indonesia berpenduduk mayoritas Islam, maka tentu system Muslim Law yang implementasinya lahir Undang-undang No. 7 Tahun 1989 jo. Undang-undang No. 3 tahun 2006 jo. Undang-undang No. 50 tahun 2009 tentang Peradilan Agama, yakni peradilan bagi orang-orang yang beragama Islam.

Akhirnya tidaklah berlebihan kalau dipertegas bahwa sistem hukum yang berlaku saat ini bersumber dari sistem hukum adat, hukum Islam, dan hukum Barat. Ketiga komponen itulah yang mengilhami sistem hukum Indonesia. Oleh karena itu, benar pendapat Achmad Ali, Indonesia sebenarnya menganut Mixed Systematau sistem hukum Hibrida. Pengimplementasian mixed system di pengadilan telah bercampur antara peraturan perundang-undangan (civil Law system) dan nilai-nilai hukum yang hidup di masyarakat (common law system) serta adanya peradilan agama Islam bagi orangorang yang beragama Islam (Muslim law system), meskipun tidak dianut secara murni dan konsekwen tetapi menyesuaikan perkembangan kehidupan dan peradaban masyarakat.

\section{F. Integrasi Hukum Positif dengan Budaya Daerah}

Telah digambarkan pada halaman terdahulu bahwa hukum positif atau ius contitutum adalah hukum yang dinyatakan berlaku oleh otoritas tertinggi dalam suatu negara dalam suatu waktu dan tempat tertentu seperti dalam Pasal 7 ayat (1) dan Pasal 8 Undang-undang No. 12 tahun 2011 Tentang Pembentukan PeraturanPerundangUndangan.

Sedangkan budaya adalah hasil karya cipta dan karsa manusia, sehingga budaya sering dipersepsi, dipahami dan dipandang sebagai sistem makna atau pengetahuan dan sistem nilai.

Budaya sebagai sistem makna melahirkan ide-ide kognitif, sistem nilai melahirkan ide-ide normatif. Dalam hubungannya dengan hukum, Daniel S. Lev, menguraikan bahwa budaya hukum diartikan sebagai nilai-nilai yang terkait dengan hukum dan proses hukum. Budaya hukum mencakup dua komponen pokok yang saling berkaitan, yakni nilai-nilai hukum substantif dan nilai-nilai hukum keacaraan. Nilai-nilai hukum substantif berisikan asumsi-asumsi fundamental mengenai distribusi dan penggunaan sumber daya di dalam masyarakat, apa yang secara sosial dianggap benar atau salah, dan seterusnya. Nilai-nilai hukum keacaraan mencakup sarana pengaturan sosial maupun pengelolaan konflik yang terjadi di dalam masyarakat. ${ }^{23}$

Pengintegrasian antara hukum positif dengan budaya daerah penting bagi politk

${ }^{23}$ Soerjono Soekanto, Faktor-faktor yang Mempengaruhi Penegakan Hukum (Jakarta: PT. Raja Grafindo, 2010), h. 8. 
hukum nasional bangsa Indonesia karena hukum positif tersebut akan diberlakukan dalam masyarakat yang kehidupannya diwarnai nilai-nilai budaya. Menurut Sudiman Kartohadiprojo, untuk menata dan menentukan isi hukum yang akan diberlakukan di Indonesia, sangat tergantung dari dua hal, yakni politik hukum penguasa dan kesadaran hukum bangsa Indonesia. ${ }^{24}$

Bagir Manan, penegakkan hukum yang tidak mengindahkan berbagai kenyataan, akan dirasakan sebagai sesuatu yang asing bahkan mungkin menekan masyarakat adalah suatu bentuk penegakan hukum yang tidak adil atau tidak berkeadilan. ${ }^{25}$

Lebih lanjut Bagir Manan mengemukakan, lingkungan sosial sebagai tempat hukum berlaku. Telah diutarakan "situation gebundenheit" hukum baik dalam pembentukan maupun penegakannya sangat dipengaruhi oleh kenyataankenyataan baik sosial, ekonomi, politik maupun budaya. ${ }^{26}$

Eugen Erlich, pemuka aliran sosiologi hukum dalam Mohtar Kusumaatmaja, antara lain telah mengemukakan hubungan hukum positif dengan budaya daerah dalam hal ini hukum yang hidup "bahwa hukum positif yg baik (dan karenanya hukum positif) adalah hukum yang sesuai dengan living law yang sebagai inner order dari masyarakat mencerminkan nilai-nilai yang hidup di dalamnya. Oleh karena itu di dalam pembuatan undang-undang hendaklah

\footnotetext{
${ }^{24}$ E. Sundari \& Endang Sumiarni, Polirik Hukum \& Tata Hukum Indonesia, h. 6.

25 Bagir Manan, Penegakan Hukum Yang Berkeadilan, Varia Peradilan No. 248, 2005. h. 9.

${ }^{26}$ Bagir Manan, Penegakan Hukum Yang Berkeadilan, h. 9.
}

diperhatikan apa yang hidup di dalam masyarakat. ${ }^{27}$

Dengan demikian integrasi hukum positif dan budaya daerah adalah suatu kebutuhan yang prinsip untuk diterjemahkan dalam penegakan hukum atau implementasi hukum. Sebab tidak terbantahkan suatu norma / aturan yang tertuang dalam undang-undang yang secara tegas dinyatakan berlaku, akan tetapi dalam tarap impelemtasi/pelaksanaan salah satu pasalnya tidak diterapkan karena tidak sesuai dengan budaya di mana hukum itu diterapkan. Demkian pulan suatu peritiwa hokum yang tidak diatur dalam huum positif, sedangkan peitiwa tersebut harus diberi hokum sehingga perlu konstruksi hokum, berikut contoh dari masalah tersebut,

1. Pasal 282 KUHPidana yang merumuskan bahwa barang siapa: menyiarkan, mempertontonkan atau menempelkan dengan berterangterangan suatu tulisan yang diketahui isinya, atau suatu gambar atau barang yang dikenalnya yang melanggar perasaan kesopanan, ..........dst dihukum penjara selama-lamanya satu tahun empat bulan.

Apabila Pasal 282 KUHPidana sebagai hukum positif karena dinyatakan berlaku benar-benar diberlakukan, maka bisa para petugas keluarga berencana (KB) yang mempertontongkan "kondom" atau sejenisnya sebagai orang yang melanggar pasal tersebut sehingga harus dihukum, karena "kondom" atau sejenisnya adalah suatu gambar atau barang yang dikenalnya melanggar perasaan kesopanan. Akan tetapi

${ }^{27}$ B. Hestu Cipto Handoyo, Hukum Tata Negara Indonesia (Cahaya Yogyakarta: Atma Pustaka, 2015), h. 37. 
ternyata petugas $\mathrm{KB}$ tidak dikena hukum, sebab petugas KB adalah menjalankan program pemerintah sehingga demi bangsa dan negara petugas KB dibekali kebal hukum terhadap pasal 282 KUHPidana. Alias hukum positif (Pasal 282 KUHPidana) tidak diberlakukan demi kepentingan bangsa dan negara termasuk di dalmnya kepentingan daerah.

Sebab tidak dapat dibayangkan pertumbuhan jumlah penduduk akan besar bilamana tidak ada program $\mathrm{KB}$ (Keluarga Berencana) dengan mempertontonkan gambar porno (kondom dan sejenisnya) yang tentu melanggar perasaan kesopanan sebagaimana dimaksud dalam pasal 282 KUHPidana di atas.

2. Pasal 404 KUHPidana, yang merumuskan; hukuman penjara selamalamanya dua tahun

(1) Barangsiapa dengan sengaja mencabut barangnya sendiri atau barang orang lain untuk keperluan yang punya, kepada orang yang mempunyai hak gadai, hak tahan, hak memungut hasil atau hak pakai atas barang itu;

(2) Barangsiapa dengan sengaja mencabut sama sekali atau sebagian dari barangnya sendiri, atau barang orang lain untuk keperluan yang punya, dari perjanjian utang hypotheek atas barang itu.

(3)dst.

Apabila pasal tersebut sebagai hukum positif benar-benar diberlakukan, maka para dialer kendaraan bermotor (pembiayaan) yang melakukan penarikan atas barangnya sendiri karena pihak pembeli dengan kredit tidak membayar angsurannya akan dihukum, maka para pembiayaan bisa bangrut dan gulung tikar, sebab oknum-oknum yang mempunyai etiked tidak baik akan tidak melunasi kewajibannya yang tentu bertentangan dengan budaya malu di daerah setempat.

Karena itu, pada umumnya masyarakat tidakkeberatan alias tidak melaporkan tindakan pembiayaan yang menarikbarang sendiri sebagimana makusd Pasal 404 KUHPidana di atas karena pembeli dengan kredit (Kreditur) tidak melunasi angsurannya sesuai waktu yang ditentukan.

3. Putusan Pengadilan Negeri Makassar yang mengabulkan permohonan Sri Wahyuni yang meminta jenis kelaminnya digiganti dari perempuan menjadi laki-laki.

Secara yuridis formal, belum ada aturan yang menggariskan cara wanita mengganti jenis kelaminnya menjadi laki-laki, tetapi untuk kebutuhan praktik hokum, hakim mebuat konstruksi hokum sehingga permohonan Sri Wahyni dikabulkan.

4. Budaya atau kebiasaan yang tidak diatur dalam hukum positif (tidak diatur dalam undang-undang yang ditetapkan) namun dipatuhi oleh warga masyarakat, sebab apabila tidak dipatuhi kebiasaan tersebut akan menciptakan maut bagi orang yang tidak mematuhinya.

Sebagai contoh:

- Setiap pengendara sepeda motor di jalan raya, berjalan di sebelah kiri. Berjalan di sebelah kiri, itu adalah kebiasaan yang sudah diterapkan oleh nenek moyang kita sebelum ada undang-undang lalu lintas jalan atau sebelum ada hukum positif, kalau kebiasaan atau budaya jalan di sebeleh kiri itu dilanggar, maka 
maut akan menjemput kita, akan terjadi kecelakaan beruntun.

- Masih dalam situasi jalan raya, khusus untuk Selawesi Selatan dan Barat, bagi pengendara mobil dari arah Mamuju, Sulawesi Barat menuju Makassar. Keadaan jalan di Kabupaten Majene, Polewali Mandar, dan Pinrang, mendahului kendaraan harus disebelah kanan, kalau tidak maka budaya setempat bisa menimbulkan perkelahian karena menurutnya dianggap kurang ajar (tidak beretika). Akan tetapi setelahemasuki wilayah hukum Kabupaten Barru, maka budaya mendahului (melambung) tidak lagi harus di sebelah kanan, akan tetapi dapat saja di sebelah kanan atau di sebelah kiri, duaduanya bisa yang penting hati-hati.

Banyak contoh-contoh lain lagi yang dapat dikemukakan tentang adanya budaya yang justru menciptakan kedamaian dalam penegakan hukum dengan membuat hukum positif menjadi tidak berlaku atau hukum tertidur (sleeping law). Aturan hukum yang secara yuridis formal tetap berlaku, tetapi terabaikan.

Dengan contoh tersebut di atas adalah bukti pentingya integrasi (penyatuan) hukum positif dengan budaya daerah kehidupan berbangsa dan bernegara.

Itulah sebabnya sehingga dalam Pasal 5 ayat (1) Undang-undang Kekuasaan Kehakiman, menggariskan bahwa hakim dan hakim konstitusi wajib menggali, mengikuti, dan memahami nilai-nilai hukum dan rasa keadilan masyarakat. Nilainilai menjadi faktor non hukum.

Faktor-faktor non hukum dimaksud dalam proses persidangan sebagai wujud dari penegakan hukum (mewujudkan ide- ide hukum) merupakan sesuatu yang lumrah dan mendapat perhatian, seperti yang dikemukakan oleh Talcot Parsons, dengan sebutan konsep Sibernetik bahwa: Hukum dalam masyarakat berdampingan dengan subsitem-subsistem bidang lain, yaitu:

a. Subsitem kebudayaan dengan fungsi untuk mempertahankan pola (pattern maintenance);

b. Subsitem sosial dengan fungsi untuk integrasi (integration);

c. Subsitem politik dengan fungsi mencapai tujuan (goal pursuance);

d. Subsitem ekonomi dengan fungsi untuk adaptasi (adaptation). ${ }^{28}$

Fajlurrahman

Jurdi, menguraikan, hukum selain membangun kerangka dasar untuk berpihak ke kepada keadilan, kepastian, kemanfaatan, ia juga meletakan postur hukum pada fakta-fakta, sehingga hukum tidak buta pada fakta, tidak tuli suara-suara nyaring masyarakat, juga tidak lumpuh berdiri dalam bangunan pengadilan semata. Hukum harus "berlari kencan" untuk mengajak berdialog dengan realitas sosial, hukum harus "ramah" menyapa setiap tradisi dan kultur dalam komunitas, hukum harus "cerdas" membaca setiap perubahan sosial, hukum harus responsif pada setiap tuntutan masyarakat, karena hukum ada "bukan untuk hukum", tetapi "hukum lahir untuk masyarakat". Jadi hukum adalah merupakan instrument politik, ekonomi, sosial dan kebudayaan untuk merekayasa diri dengan batasan-batasan. ${ }^{29}$

Integrasi hukum positif dengan budaya daerah kita dapat melihat kualitas

${ }^{28}$ Achmad Ali, Menguak Tabir Hukum Suatu Kajian Filosofis dan Sosiologis, (Jakarta: Ghalia Indonesia, 2008), h. 219.

29. Aswanto, Hukum dan Kekuasaan Relasi Hukum, Politik dan Pemilu (Yogyakarta: Rangkang Education, 2012), h. $\mathrm{x}$ 
kepatuhan hukum oleh warga negara dengan tiga jenis kepatuhan yang dikemukakan oleh H. C. Kelman, berikut:

1. Ketaatan yang bersifat compliance, yaitu jika seorang taat terhadap aturan hukum hanya karena takut akan sanksi;

2. Ketaatan yang bersifat identification, yaitu jika seorang taat terhadap suatu aturan hukum hanya karena menjaga hubungan baiknya dengan seseorang agar tidak rusak.

3. Ketaatan yang bersifat internalization, yaitu jika orang taat terhadap suatu aturan hukum benar-benar karena ia merasa aturan itu sesuai dengan nilainilai intrinsik yang dianutnya. ${ }^{30}$

Dengan pentingnya integrasi (penyatuan) hukum positif dengan budaya daerah, agar masyarakat mematuhi hukum ada pada tingkat ketiga yang digambarkan oleh H. C. Kelman tersebut di atas yang dinamainya "ketaatan yang bersifat internalization", yaitu ketaatan karena sesuai dengan nilai-nilai hukum yang hidup atau jiwa warga yang mematuhi hukum tersebut, maka pembentukan peraturan perundang-undangan oleh para legal darfter sedapat mungkin tetap memperhatikan keberlakuan hukum yang akan diciptakan dengan tiga alat ukur, yakni:

1. Keberlakuan yuridis,

Menurut Bagir Manan, Keberlakuan yurudis diperinci menjadi beberapa syarat;

Pertama; keharusan adanya kewenangan dari pembuat peraturan perudang-undangan. Setiap peraturan perundang-undangan harus dibuat oleh badan atau pejabat yang berwenang. Jika tidak maka peraturan perundang-

${ }^{30}$ Achmad Ali \& Wiwie Heryani, Menjelajahi Kajian Empiris Terhada Hukum (Jakarta: Prenada Media Group, 2012), h. 142. undangan itu batal demi hukum (dianggap tidak pernah ada).

Kedua; keharusan adanya kesesuaian bentuk atau jenis atau peraturan perundang-undangan dengan materi yang diatur, terutama kalau diperintah oleh peraturan perundang-undangan yang lebih tinggi atau sederjat.

Ketiga; keharusan mengikuti tata cara tertentu. Apabila tata cara tersebut tidak diikuti, maka peraturan perundangundangan tersebut batal demi hukum atau tidak/belum memiliki keekuatan hukum yang mengikat. Misalnya Peraturan Daerah dibuat bersama-sama DPRD dan Kepala Daerah, kalau ada peraturan daerah tidak mencantumkan persetujuan DPRD maka batal demi hukum.

Keempat; Keharusan tidak bertentangan dengan peraturan perundang-undangan yang lebih tinggi tingkatannya. Misalnya undang-undang tidak boleh bertentangan dengan Undang-Undang Dasar, Peraturan Pemerintah tidak boleh bertentangan dengan undang-undang, peraturan daerah tidak boleh bertentagan dengan Peraturan pemerintah.. dst.

2. Keberlakuan Sosiologis,

Dasar keberlakuan sosiologis maksudnya adalah jika para warga masyarakat mematuhi hukum dimana hukum itu diberlakukan.

3. Keberlakuan Filosofis,

Setiap masyarakat mempunyai "rechtsidee" yakni apa yang warga masyarakat harapkan dari hukum, misalnya hukum diharapkan untuk menjamin adanya keadilan, kemanfaatan dan ketertiban mapun kesejahteraan. Cita hukum atau rechtsidee tumbuh dalam sistem nilai masyarakat tentang baik dan buruk, pandangan mereka mengenai hubungan individu dan 
masyarakat dan lain sebagainya termasuk pandangan tentang dunia gaib. $^{31}$

Contoh yang sangat populer dalam

Islam, yang menggambarkan keberlakuan hukum secara yuridis, sosiologis dan filosofis dengan ketaatan yang bersifat internalizatioan dapat ditemukan dalam riwayat dialog antara Nabi Muhammad dengan Muaz, yang terkenal dengan Hadis Muaz bin Jabal, menjelang Muaz bin Jabal diutus sebagai Gubernur Yaman, diriwayatkan terjadi dialog antara Rasulullah SAW. dengan Muaz bin Jabal sebagai berikut: "Wahai Muaz, bagaimana atau dengan apa kamu memecahkan persoalan agama"? Muaz menjawab, "Aku akan merujuk kepada Kitab Allah”. Lebih lanjut Rasulullah SAW. bertanya lagi, "Andaikan kamu tidak mendapatkan jawabannya dalam Kitab Allah"? Muaz menjawab, "Aku akan mencari jawabannya di dalam Sunnah RasulNya." Rasulullah SAW. melanjutkan bertanya, "Andaikan kamu juga tidak mendapatkan jawabannya di dalam Sunnah Rasul-Nya"? dengan tegas Muaz menjawab, "Aku akan berijtihad dengan mendapatkan sendiri." Mendengar jawaban tersebut, wajah Rasulullah SAW tampak cerah seraya berkata, segala puji bagi Allah yang telah memberi petunjuk kepada utusan Rasul-Nya. ${ }^{32}$

\footnotetext{
${ }^{31}$ Sirajuddin et.al., Legislative Drafting Pelembagaan Metode Partispatif Dalam Pembentukan Peraturan Perundang-undangan (Malang: Setara Press, 2015), h. 22-25.

32 Muhammad Alim, Penyesatan Melalui Teori (Jakarta: Mahkamah Agung, Varia Peradilan No.339 Februari 2014), h. 48-49.
}

\section{G. Kesimpulan}

Integrasi Hukum Positif dengan Budaya Daerah adalah penyatuan hukum positif sebagai hukum yang ditetapkan oleh otoritas tertinggi dengan nilai-nilai hukum yang hidup dalam masyarakat agar warga masyarakat patuh terhadap hukum berada dalam taraf patuh yang bersifat internalization (patuh karena sesuai dengan nilai-nilai yang hidup pada warga masyarakat yang diatunya) demikian pula terhadap peristiwa hukum tidak diatur dalam hukum positifr dapat dibuat konstruksi hukum oleh hakim dengan berpedoman pada nilai-nilai budaya atau nilai-nilai hukum di masyarakat.

Dalam pembentukan hukum positif sebagai hukum yang ditetapkan oleh otoritas tertinggi dalam masyarakat tetap memperhatikan budaya daerah, karena dengan memperhatikan budaya daerah maka keberlakuan peraturan perundangundangan dari barometer keberlakuan sosiologis dan filosofi dapat terpenuhi. Keberlkaun sosiologis dan filosopi menjadi pengukur yang prinsip untuk diperhatikan, sebab akan mempengaruhi diterima atau tidaknyasuatu peraturan perundangundangan bagi masyarakat yang diaturnya.

\section{Daftar Pustaka}

Abdul Kadir Muhammad, 2006. Etika Profesi Hukum Citra Aditya Bakti, Bandung.

Achmad Ali, 2008. Menguak Tabir Hukum Suatu Kajian Filosofis dan Sosiologis, Ghalia Indonesia, Jakarta. 
Achmad Ali, 2012.Menjelajahi Kajian Empiris Terhadap Hukum Kencana, Jakarta.

Anthon F. Susanto, 2017. Hukum dari Consilience ke Pradigma Hukum Konstruktif-Transgresif, Rafika Aditama, Bandung.

Aswanto, 2012.Hukum dan Kekuasaan Relasi Hukum, Politik dan Pemilu, Rangkang Education, Yogyakarta.

Bagir Manan, 2005. Penegakan Hukum Yang Berkeadilan, Varia Peradilan, Mahkamah Agung, Jakarta.

B. Hestu Cipto Handoyo, 2015. Hukum Tata Negara Indonesia, Cahaya Atma Pustaka, Yogyakarta.

E. Sundari \& M.G. Endang Sumiarni, 2015. Politik Hukum \& Tata Hukum Indonesia, Cahaya Atma Pustaka, Yogyakarta.

Harsya Bachtiar, 1986.Sistem Budaya di Indonesia, Budaya dan Manusia di Indonesia, Hanindita, Yogyakarta.

Jimly Asshidiqie, 2009.Menuju Negara Hukum Yang Demokratis, PT. Bhuana Jakarta.
Kahar, 2016. Menguak Penemuan Hukum Berwibawa, Gunadarma Ilmu, Samata-Gowa.

Moh. Mahfud MD, 2009. Politik Hukum di Indonesia, Rajawali Pers, Jakarta.

Muhammad Alim, 2015. Penyesatan Melalui

Teori, Mahkamah Agung Varia Peradilan No.339, Jakarta.

M. Syamsuddin, 2012.Konstruksi Baru Budaya Hukum Hakim Berbasis Hukum Progresif, Kencana Prenada Media Group, Jakarta.

Salim HS, 2012.Perkembangan Teori dalam Ilmu Hukum, Rajawali Pres, Jakarta.

Sirajuddinet.al., 2015. Legislative Drafting Pelembagaan Metode Partispatif Dalam Pembentukan Peraturan Perundang-undangan, Setara Press, Malang.

Soerjono Soekanto, 2010. Faktor-Faktor Yang Mempengaruhi Penegakan Hukum, Raja Grafindo Persada, Jakarta.

Umar Said Sugiarto, 2013.Pengantar Hukum Indonesia Sinar Grafika, Jakarta.

Departemen Pendidikan Nasioanl, 2003.Kamus Besar Bahasa Indonesia, Balai Pustaka, 